\title{
Science classroom activities and student situational engagement
}

\author{
Inkinen, Janna
}

2019

Inkinen , J , Klager , C , Schneider , B , Juuti , K, Krajcik, J , Lavonen , J \& Salmela-Aro , K 2019 , ' Science classroom activities and student situational engagement ' , International Journal of Science Education , vol. 41 , no. 3 , pp. 316-329 . https://doi.org/10.1080/09500693.2018.1549372

http://hdl.handle.net/10138/301096

https://doi.org/10.1080/09500693.2018.1549372

Downloaded from Helda, University of Helsinki institutional repository.

This is an electronic reprint of the original article.

This reprint may differ from the original in pagination and typographic detail.

Please cite the original version. 
SCIENCE CLASSROOM ACTIVITIES

Inkinen J., Klager, C., Schneider, B., Juuti, K., Krajcik, J., Lavonen, J., \& Salmela-Aro, K. (2019). Science classroom activities and student situational engagement. International Journal of Science Education, 41(3), 316 - 329

https://doi.org/10.1080/09500693.2018.1549372

This is an electronic reprint of the original article.

This reprint may differ from the original in pagination and typographic detail.

Please cite the original version. 
SCIENCE CLASSROOM ACTIVITIES

Word count: Abstract (209), Main text (5721), Tables (490)

Science Classroom Activities and Student Situational Engagement

\author{
Inkinen Janna ${ }^{\mathrm{a}}$ \\ janna.inkinen@helsinki.fi \\ Klager Christopher ${ }^{\mathrm{b}}$ \\ Schneider Barbara ${ }^{\mathrm{b}}$ \\ Juuti Kalle ${ }^{\mathrm{a}}$ \\ Krajcik Joseph ${ }^{\mathrm{b}}$ \\ Lavonen Jari ${ }^{\mathrm{a}, \mathrm{c}}$ \\ Salmela-Aro Katariina ${ }^{a}$
}

\footnotetext{
${ }^{\text {a }}$ Faculty of Educational Sciences, University of Helsinki, Finland

Siltavuorenpenger 5 PL 9, 00014 University of Helsinki

${ }^{\mathrm{b}}$ College of Education, Michigan State University, East Lansing, Michigan, United States

620 Farm Ln, 516 Erickson Hall, East Lansing, MI 48824

${ }^{\mathrm{c}}$ Department of Childhood Education, University of Johannesburg, Soweto, South Africa
}

This work was supported by the Academy of Finland under Grant [No. 298323 - PI Katariina Salmela-Aro] and [No. 294228 - PI Jari Lavonen], and the National Science Foundation under Grant [No. 1450756 \& No. 1545684 - PIs Barbara Schneider and Joseph Krajcik]. Research findings and interpretations are those of the authors and not of the funding agencies. Data and code related to this project will eventually be available at http://doi.org/10.3886/E100380V1 
SCIENCE CLASSROOM ACTIVITIES

\section{Abstract}

This study examines the association between student situational engagement and classroom activities in secondary school science classrooms in Finland and the U.S. Situational engagement is conceptualized as times when students feel that a task is interesting to them, challenging, and yet that they have the skills to complete it (see Schneider et al., 2016). Data on situational engagement and classroom activities were obtained using the experience sampling method (ESM) from 247 Finnish students in 12 secondary science classrooms and 281 U.S. students in 18 secondary science classrooms. In both samples, students tend to be situationally engaged only a small proportion of the time during their science classes. However, Finnish students were more likely than U.S. students to report being situationally engaged. To investigate when students were most likely to report being situationally engaged, hierarchical logistic regression models were employed, suggesting that some classroom activities are associated with higher levels of student situational engagement than others. Finnish students were more likely to report being situationally engaged when calculating and presenting scientific information. In the U.S., students were more likely to report being situationally engaged while discussing scientific information and less likely when listening to the teacher. Results suggest that situational engagement is momentary and associated with specific science classroom activities.

\section{Keywords:}

Situational engagement, science, classroom activities, experience sampling method 
SCIENCE CLASSROOM ACTIVITIES

\section{Introduction}

Student engagement is a multidimensional concept encompassing the academic, cognitive, and social behaviours of individuals when involved in specific activities (Finn \& Zimmer, 2012; Fredricks, Blumenfeld, \& Paris, 2004). Students who are academically and socially engaged are likely to have higher achievement at school and receive positive responses from their teachers (Finn \& Zimmer, 2012). Engaged students are also more likely to use effective learning strategies (Krapp, 2000), show higher levels of self-regulation and effort (Lee, Lee, \& Bong, 2014), and spend more time on learning tasks (Ainley, Hidi, \& Berndorf, 2002). Although researchers have focused on the benefits of being engaged, fewer studies have investigated how to support students' enjoyment and enhance their sense of accomplishment when involved in particular science learning activities (Velayutham, Aldridge, \& Fraser, 2011).

While research shows the importance of engagement for learning, there are multiple questions about the intensity and duration of being engaged. Several researchers have argued that engagement is not an omnibus construct but rather one that is influenced by specific tasks and occurs at certain times (Hidi \& Renninger, 2006; Schneider et al., 2016). These scholars have argued that engagement should be examined when students are involved in tasks where interest and other emotions affect their attention and motivation. By studying situational engagement with this conception, it allows scholars and teachers to identify and monitor what instructional activities are associated with situational engagement (Good \& Brophy, 2003; Shernoff, Csikszentmihalyi, Schneider, \& Shernoff, 2003). Yet few studies focus on a wider set of activities, especially ones that are infrequently used in science classes such as multiple-disciplinary activities like solving mathematical problems (HampdenThompson \& Bennett, 2013). This study examines a diverse set of activities in science classrooms and their relationship to elevated levels of student situational engagement. 
SCIENCE CLASSROOM ACTIVITIES

Student engagement and its relationship to other social and emotional indicators have typically been measured using retrospective questionnaires (e.g. Ainley \& Ainley, 2011; Hampden-Thompson \& Bennett, 2013; Lavonen \& Laaksonen, 2009; Salmela-Aro \& Upadyaya, 2014). Retrospective questionnaires, while sometimes very useful, only capture students' experiences as one-time assessments of events that may have occurred weeks or months before. There is a need for measurement tools that collect information from students in actual learning situations, particularly when attempting to identify when and in what activities student engagement is likely to vary, both in time and social and emotional intensity.

To overcome the retrospective problem of questionnaires we use the experience sampling method (ESM) to measure situational engagement during actual science learning activities (see Hektner, Schmidt, \& Csikzentmihalyi, 2007; Salmela-Aro, Moeller, Schneider, Spicer, \& Lavonen, 2016). The ESM captures behaviours and subjective experiences across multiple contexts by means of self-reports (Hektner et al., 2007). The data are obtained immediately, as students answer signals transmitted to hand-held devices such as smartphones, programmed to emit prompts on a randomized schedule. This immediate data collection effort by the ESM helps to reduce general recall bias and specific instances that may overshadow "a true response to a real situation" (Mulligan, Schneider, \& Wolfe, 2005). There have been several questions regarding the use of the ESM with respect to respondent burden, disruption, and missing data. One possible disadvantage of the ESM is that it can interrupt a desired outcome such as student situational engagement. However, Hektner and others (2007) and Jeong (2005) have addressed these concerns, finding that they do not significantly affect the quality of the data especially when compared to other types of data collection. For example, when designing an ESM study, researchers carefully consider how many days' participants will report their experiences and how many times per day they will 
SCIENCE CLASSROOM ACTIVITIES

receive the ESM questionnaire (Hektner et al., 2007). The time that it takes to complete the ESM questionnaire is another factor that influences the burden on respondents, so researchers must limit the length of the survey. Because the data collection itself can be burdensome and lead to nonresponse, participants may need special incentives to actively participate in ESM studies (Jeong, 2005).

This study focuses on examining the relationship between student situational engagement and different classroom activities that their secondary school teachers used in Finland and the U.S. during upper secondary (high school) science lessons. Hierarchical logistic regression models were employed to examine the relationship between specific classroom activities and whether they were associated with elevated levels of student situational engagement. The primary research question addressed in this investigation is: To what degree are classroom activities associated with student situational engagement in secondary science classes?

\section{Student Situational Engagement}

Different aspects of student engagement in science learning have been the focus of studies in psychology and science education (Fredricks et al., 2004; Osborne, Simon, \& Collins, 2003; Salmela-Aro et al., 2016). We adopt Schneider and colleagues' (2016) conceptualization of situational engagement - a concept that they refer to as optimal learning moments — which is when a student experiences a high level of interest, skill, and challenge at the same time.

This definition is based on Csikszentmihalyi's (1990) idea of flow that highlights the role of students' skills related to the challenge of the ongoing task. Even though there have been argumentations against the definition of situational engagement through flow theory in school context (e.g. Brophy, 2004; Upadyaya \& Salmela-Aro, 2013), 
SCIENCE CLASSROOM ACTIVITIES

the flow theory originally supports the examination of situational engagement in classroom situations (e.g. Csikszentmihalyi, 1990; 2014). School and classroom contexts are guided by clear goals, rules and feedback that increases the possibility for students being situationally engaged (Csikszentmihalyi \& Schneider, 2000). Furthermore, situational engagement, according to flow theory, occurs only when students' evaluation of their skills are high together with the estimated challenge of the ongoing task (Csikszentmihalyi, 1990).

The definition of situational engagement requires three preconditions - interest, skill and challenge - to be present. These preconditions, however, behave and relate to each other in different ways. For example, situational interest towards an ongoing task maintains when students feel that they have proper skills and knowledge to complete the task (Schneider et al., 2016). At the same time, the balance between skill and challenge is important, because there are other psychological states - apathy, relaxation and anxiety - that competes with situational engagement (Nakamura \& Csikszentmihalyi, 2014; Shernoff \& Csikszentmihalyi, 2009).

Situational interest is a fundamental aspect of situational engagement, setting the foundation for continuing motivation and subsequent learning (Shernoff et al., 2003). Situational interest guides students to work and to persist with the on-going task. Situational interest is topic specific and a result of an interaction between a person and environment (Hidi, Renninger, \& Krapp, 2004). In this research, we consider the environment to be the ongoing task.

Skills are defined as domain-specific (Brophy, 2008), or in other words, students' skills are task-specific. When students feel skilled they evaluate that they can master the on-going task which keeps them working towards an aim. However, a high level of skill does not directly lead to situational engagement as the self-evaluation of skill is 
SCIENCE CLASSROOM ACTIVITIES

related to the difficulty or challenge of the task. Challenge, that the situation offers, can be seen as relatively positive state in which students' skills meet the demands of the task (Linnansaari et al., 2015). When the learning situation exceeds students' skills and the challenge is too demanding, students are likely to become disengaged. Skill and challenge, however, are not enough to motivate and sustain engagement in an activity. The activity should be meaningful and relevant (Krajcik \& Shin, 2014) and spark an individual's interest, especially if the goal is to increase the proportion of time when students are engaged.

\section{Classroom Activities}

Students may think, feel, and act differently depending on the classroom activities in which they participate (Corso, Bundick, Quaglic, \& Haywood, 2013). Clearly there are specific instructional activities that are more likely to enhance engagement than others, such as those that are goal oriented, participatory, involve presenting material, and/or solving meaningful problems (Shernoff et al., 2003). For this study, classroom activities are classified based on work by Juuti and others (2010) and modified to reflect the variety of instructional activities teachers engage in and the time they spend on each activity (based on our ESM data and that of others, see Shernoff et al., 2003). Classroom activities include listening; discussing; laboratory work; group work; calculating; presenting scientific information; using computer; writing; and taking a test. These classroom activities have been selected so that students can easily recognize them themselves (see Juuti et al., 2010) and thus we can use student self-reports. All of these classroom activities are also frequently used in science classrooms. For example, regardless of the classroom activities that teachers are emphasizing, teachers usually include activities that require students listening to a lecture, allow students discussing with each other and working together and include individual work. 
SCIENCE CLASSROOM ACTIVITIES

When lecturing, a teacher presents new material or solves problems in front of the classroom (Lavonen, Angell, Byman, Henriksen, \& Koponen, 2007). Previous ESM studies among U.S. students reveal that lecturing seems to be associated with decreased student situational engagement (Schmidt, Rosenberg, \& Beymer, 2017; Shernoff et al., 2003). On the other hand, some research has found that interactive teaching, discussion, and questioning techniques are associated with increased student engagement (Good \& Brophy, 2003). Laboratory work has been seen as an essential learning activity in science (Duit \& Confrey, 1996; Millar, 2011). Prior studies indicate that when students are involved in laboratory activities, they experience higher levels of engagement than when tasked with individual work (Schmidt et al., 2017). But on its face, even though laboratory work has been shown to be an engaging activity, other findings show that it increases student engagement only when associated with contemporary problems (Abrahams, 2009).

When working on independent problems or tasks such as writing, calculating, solving problems, or working on a computer (Lavonen et al., 2007) student engagement can increase (Shernoff et al., 2003; Wu \& Huang, 2007). However, Schmidt et al. (2017) find that independent work in secondary science classes is associated with lower levels of engagement. We suspect that group work may be a catalyst for situational engagement (e.g. Shernoff et al., 2003). When tasks are collaborative — with all students working to investigate phenomenarelevant to everyday life, and meaningful to the person, then most of the students are more likely to be situationally engaged.

There is previous ESM research in which mathematics and computer science as school subjects were observed. According to Shernoff and others (2003) mathematics and computer science were not as engaging as other school subjects. However, mathematics, especially calculating, is often used in science to solve problems. It may be the case that some disinterest in science is due to the calculation required for solving science problems. Further 
SCIENCE CLASSROOM ACTIVITIES

studies related to classroom activities and student situational engagement should be conducted, especially related to independent problem solving such as calculating (HampdenThompson \& Bennett, 2013).

Assessment is an essential aspect of science teaching and learning. Assessments have different levels and different purposes. In Finland, there is no national- or district-level testing or inspection (Lavonen, 2007); assessment is more formative in nature. Teachers plan their tests and decide the grades for their students following national guidelines and performance criteria. There is only one national-level assessment at the end of secondary school. In the U.S., district- and state-level testing are common (Lederman \& Lederman, 2007). In addition to district-level assessment, teachers often include short tests or quizzes in their teaching. While taking a test or a quiz, students are likely to recognize the importance of the test, but not derive enjoyment from the experience (Schmidt et al., 2017). We recognize that testing has different meaning and procedures in Finland and the U.S. The intent of this study is not to directly compare Finnish and U.S. science situational engagement, but rather to illustrate when students become situationally engaged and if there are some key characteristics the students share in common. For example, when calculating do students report elevated levels of situational engagement?

\section{Methods}

The data for this study were collected in spring and fall 2015as part of a larger international study. Data on situational engagement were obtained using ESM questionnaires delivered via smartphones. Phones were programmed to signal students three times during each of their science lessons. Students had 15 minutes to answer the ESM questionnaire once they received the signal. The ESM questionnaire included students' self-evaluation of their 
SCIENCE CLASSROOM ACTIVITIES

situational engagement - measured via ratings of interest, skill, and challenge — and the classroom activities they were participated in.

\section{Participants}

The Finnish sample consisted of 13 secondary science classrooms in three schools-one urban and two suburban - in the Helsinki area. In two schools, students had high levels of achievement as determined by formative assessments and the results of international and national exams conducted at the end of their high school studies. In the third school, the students had average levels of achievement. The 18 classrooms in seven U.S. schools - two urban, three suburban, and two rural—were located in Michigan. Academic performance ranged from high to low based on state assessment results. Altogether 247 students participated in Finland and 281 in the U.S. In Finland, there were two biology, four physics, and six chemistry teachers. In the U.S. there were three biology, eight chemistry, and seven physics teachers. This resulted in 4432 ESM responses in Finland and 3795 ESM responses in the U.S.

\section{Measuring Student Situational Engagement and Classroom Activities}

The index for situational engagement was derived from students' responses about their level of agreement with the following three statements "Were you interested in what you were doing?", "Did you feel skilled at what you were doing?", and "Did you feel challenged by what you were doing?". A four point Likert -scale with the response categories 'strongly agree' $=4$, 'agree' $=3$, 'disagree' $=2$ and 'strongly disagree' $=1$ was used. To be situationally engaged, students must have answered 'agree' or 'strongly agree' to all of the questions related to skill, interest, and challenge. If so, a binary variable for being situationally engaged 
SCIENCE CLASSROOM ACTIVITIES

was calculated as a one, otherwise students received a zero indicating a low level of engagement. The four point Likert -scale questions were used to assess the variability of students' experiences of skill, interest and challenge which was then converted to a binary score. The binary analysis is a replication of [Authors 1] (year). Furthermore, the four point Likert - scale questions were thought to be easier for students to respond comparing to the evaluation of their experience of situational engagement.

The instruments were translated into Finnish and English for the respective sample of students. All of these instruments were piloted in both countries to ensure that the meaning of the questions was comparable. High levels of skill, interest and challenge were not routinely experienced together $\left(\alpha_{\mathrm{fin}}=.46, \alpha_{\text {us }}=.40\right)$, but the theory behind situational engagement(Schneider et al., 2016) predict that identifying contexts in which they are experienced simultaneously may hold an important key to understanding student situational engagement (see also Shernoff et al., 2003). We do not expect that students experience the same amount of skill, interest and challenge when working among a task - thus the reliability of the occurrence of skill, interest and challenge is rather low. However, we assume that all of the preconditions are needed for students to be situationally engaged. Furthermore, low alpha can be seen as an evidence for fluctuation of skill, interest and challenge in science lessons providing support for the definition of situational engagement though these preconditions.

Students were also asked to select one main classroom activity that they were doing right as the ESM questionnaire came. These classroom activities were: listening, discussing, writing, calculating, testing, using a computer, working in a group, working in the laboratory, presenting, and “other". Binary variables were created to indicate if the student reported each activity at the time they were signalled. 
SCIENCE CLASSROOM ACTIVITIES

\section{Analysis Procedures}

First, descriptive statistics were run to reveal how much time students spent on different classroom activities and what percentage of the responses students reported being situationally engaged.

To learn when students were the most situationally engaged we ran a series of three-level hierarchical logit models with responses at level one nested within students at level two and classrooms at level three. Such models account for the clustered nature of the data when calculating standard errors (Raudenbush \& Bryk, 2002). The outcome was a binary indicator of whether the student was situationally engaged or not. Binary indicators were constructed for activities reported by the students. Models were estimated for each classroom activity category as follows: the coefficients represent comparisons between the activity examined in the model (listening, discussion, writing, calculating, testing, using a computer, working in a group, working in the laboratory, presenting, and other) and situations where all the others were present. Every student answered to the ESM questionnaire independently so the total number of responses varied from 1 to 36 depending on how many times each individual answered the ESM questionnaire. Overall, there were 12 science lessons in both countries where each student participated in the data collection. In every science lesson there were three signals which made the maximum number of students' answers 36 . The hierarchical logistic regression model used was:

Level 1 - Responses

$\operatorname{logit}(\pi i \dot{i} t i j)=\beta_{0 i j}+\beta_{1 i j} X_{t i j} \dot{i}$

Level 2 - Students

$\beta_{0 i j}=\gamma_{00 j}+v_{0 i j}$ $\beta_{1 i j}=\gamma_{10 j}$ 
SCIENCE CLASSROOM ACTIVITIES

Level 3 - Classrooms

$\gamma_{00 j}=\delta_{000}+\eta_{00 j}$

$\gamma_{10 j}=\delta_{100}$

where $\pi_{t i j}$ is a binary indicator of situational engagement for response $t$ from student $i$ in classroom $j$ and $X_{t i j}$ is a binary variable indicating whether student $i$ was participating in the activity category of interest at time $t$. We converted the odds ratios from the hierarchical models into predicted probabilities for the statistically significant coefficients. This allowed us to see the magnitude of the change in situational engagement.

Analysis were run separately for each country. We used STATA 14.2 for analysis.

\section{Results}

Tables 1 and 2 present descriptive results of the times when students were situationally engaged and how much time they spent in each activity. In Finland, students reported that they spend the majority of their time listening (41\%) and the least amount of time on the computer, testing, doing laboratory work, and presenting. In the U.S., students also reported spending the majority of their time listening and the least amount of time presenting, testing, computing, and calculating. Although U.S. students spent large amounts of time listening to the teacher, it was still proportionately less than students in Finland. The major difference between the two groups is that Finnish students were doing a lot more listening, whereas the U.S. students reported more of a balance between listening (24\%) and discussing (20\%). 
SCIENCE CLASSROOM ACTIVITIES

Table 1

Summary Statistics - Finland

\begin{tabular}{|c|c|c|c|c|c|}
\hline Activity & $\begin{array}{l}\text { Time in } \\
\text { Activity }\end{array}$ & $\begin{array}{c}\text { Time Situationally } \\
\text { Engaged }\end{array}$ & Challenge & Skill & Interest \\
\hline Listening & $40.5 \%$ & $22.3 \%$ & $\begin{array}{l}2.38 \\
(.94)\end{array}$ & $\begin{array}{l}2.72 \\
(.79)\end{array}$ & $\begin{array}{l}3.06 \\
(.71)\end{array}$ \\
\hline Discussing & $10.9 \%$ & $19.8 \%$ & $\begin{array}{l}2.30 \\
(.96)\end{array}$ & $\begin{array}{l}2.78 \\
(.82)\end{array}$ & $\begin{array}{l}3.12 \\
(.69)\end{array}$ \\
\hline Writing & $12.9 \%$ & $23.2 \%$ & $\begin{array}{l}2.48 \\
(.90)\end{array}$ & $\begin{array}{l}2.70 \\
(.79)\end{array}$ & $\begin{array}{l}2.95 \\
(.74)\end{array}$ \\
\hline Calculating & $6.3 \%$ & $38.1 \%$ & $\begin{array}{l}2.89 \\
(.84)\end{array}$ & $\begin{array}{l}2.70 \\
(.83)\end{array}$ & $\begin{array}{l}3.15 \\
(.69)\end{array}$ \\
\hline Testing & $3.4 \%$ & $22.4 \%$ & $\begin{array}{l}2.26 \\
(.91)\end{array}$ & $\begin{array}{l}2.78 \\
(.86)\end{array}$ & $\begin{array}{l}2.88 \\
(.82)\end{array}$ \\
\hline Computer & $2.4 \%$ & $25.2 \%$ & $\begin{array}{l}2.36 \\
(.89)\end{array}$ & $\begin{array}{l}2.86 \\
(.86)\end{array}$ & $\begin{array}{l}3.07 \\
(.72)\end{array}$ \\
\hline Group Work & $13.4 \%$ & $22.5 \%$ & $\begin{array}{l}2.40 \\
(.86)\end{array}$ & $\begin{array}{l}2.76 \\
(.83)\end{array}$ & $\begin{array}{l}3.02 \\
(.77)\end{array}$ \\
\hline Lab Work & $3.6 \%$ & $21.7 \%$ & $\begin{array}{l}2.20 \\
(.89)\end{array}$ & $\begin{array}{l}3.07 \\
(.82)\end{array}$ & $\begin{array}{l}3.39 \\
(.71)\end{array}$ \\
\hline Presenting & $0.9 \%$ & $46.3 \%$ & $\begin{array}{l}2.56 \\
(.90)\end{array}$ & $\begin{array}{l}3.05 \\
(.71)\end{array}$ & $\begin{array}{l}3.12 \\
(.75)\end{array}$ \\
\hline Other & $5.1 \%$ & $16.2 \%$ & $\begin{array}{l}2.06 \\
(.99) \\
\end{array}$ & $\begin{array}{l}2.65 \\
(.93) \\
\end{array}$ & $\begin{array}{l}2.87 \\
(.91)\end{array}$ \\
\hline Overall & $100 \%$ & $23.1 \%$ & $\begin{array}{l}2.39 \\
(.93)\end{array}$ & $\begin{array}{l}2.75 \\
(.82)\end{array}$ & $\begin{array}{l}3.05 \\
(.74)\end{array}$ \\
\hline
\end{tabular}


Table 2

Summary Statistics - U.S.

\begin{tabular}{|c|c|c|c|c|c|}
\hline Activity & $\begin{array}{l}\text { Time in } \\
\text { Activity }\end{array}$ & $\begin{array}{c}\text { Time Situationally } \\
\text { Engaged }\end{array}$ & Challenge & Skill & Interest \\
\hline Listening & $23.8 \%$ & $15.2 \%$ & $\begin{array}{l}2.13 \\
(.98)\end{array}$ & $\begin{array}{l}2.65 \\
(.95)\end{array}$ & $\begin{array}{c}2.56 \\
(1.00)\end{array}$ \\
\hline Discussing & $19.8 \%$ & $19.5 \%$ & $\begin{array}{l}2.26 \\
(.95)\end{array}$ & $\begin{array}{l}2.72 \\
(.91)\end{array}$ & $\begin{array}{l}2.60 \\
(.95)\end{array}$ \\
\hline Writing & $15.2 \%$ & $14.7 \%$ & $\begin{array}{l}2.20 \\
(.96)\end{array}$ & $\begin{array}{l}2.73 \\
(.93)\end{array}$ & $\begin{array}{l}2.44 \\
(.96)\end{array}$ \\
\hline Calculating & $6.6 \%$ & $18.1 \%$ & $\begin{array}{l}2.44 \\
(.92)\end{array}$ & $\begin{array}{l}2.79 \\
(.93)\end{array}$ & $\begin{array}{l}2.36 \\
(.92)\end{array}$ \\
\hline Testing & $0.8 \%$ & $21.9 \%$ & $\begin{array}{l}2.72 \\
(.96)\end{array}$ & $\begin{array}{c}2.72 \\
(1.05)\end{array}$ & $\begin{array}{c}2.16 \\
(1.08)\end{array}$ \\
\hline Computer & $4.4 \%$ & $14.9 \%$ & $\begin{array}{l}2.16 \\
(.98)\end{array}$ & $\begin{array}{l}2.77 \\
(.93)\end{array}$ & $\begin{array}{c}2.54 \\
(1.07)\end{array}$ \\
\hline Group Work & $12.2 \%$ & $19.0 \%$ & $\begin{array}{l}2.25 \\
(.93)\end{array}$ & $\begin{array}{l}2.77 \\
(.91)\end{array}$ & $\begin{array}{l}2.57 \\
(.95)\end{array}$ \\
\hline Lab Work & $9.1 \%$ & $15.1 \%$ & $\begin{array}{l}2.04 \\
(.95)\end{array}$ & $\begin{array}{l}2.86 \\
(.92)\end{array}$ & $\begin{array}{c}2.72 \\
(1.01)\end{array}$ \\
\hline Presenting & $0.7 \%$ & $23.1 \%$ & $\begin{array}{l}2.00 \\
(.89)\end{array}$ & $\begin{array}{l}2.92 \\
(.74)\end{array}$ & $\begin{array}{l}2.81 \\
(.69)\end{array}$ \\
\hline Other & $7.4 \%$ & $12.1 \%$ & $\begin{array}{c}1.86 \\
(1.02) \\
\end{array}$ & $\begin{array}{c}2.65 \\
(1.09) \\
\end{array}$ & $\begin{array}{c}2.41 \\
(1.09) \\
\end{array}$ \\
\hline Overall & $100 \%$ & $16.5 \%$ & $\begin{array}{l}2.18 \\
(.97)\end{array}$ & $\begin{array}{l}2.73 \\
(.94)\end{array}$ & $\begin{array}{l}2.54 \\
(.99)\end{array}$ \\
\hline
\end{tabular}

Note. $\mathrm{N}=3795$ observations from 281 students in 18 classrooms. Standard deviations appear in parentheses below the means for challenge, skill, and interest. Challenge, skill, and interest are rated on a 1 to 4 scale ( 1 = Strongly Disagree; $4=$ Strongly Agree $)$.

With respect to the time students reported being situationally engaged, it was only a small percentage of the responses. In the U.S. it was only in about 16.5 percent of students' answers that they reported of being engaged. In Finland however, students reported being situationally engaged in about 23 percent of the responses. In the next set of Tables, 3 and 4, we present the results from our three-level hierarchical logit models.

In Finland students were 2.16 times more likely to be situationally engaged when calculating compared with all other activities - an increase of 12 percentage points, which is a substantial increase given the relatively low prevalence of situational engagement overall. Presenting 
SCIENCE CLASSROOM ACTIVITIES

also had a high odds ratio but only represented a small proportion of the time when students were situationally engaged.

Table 3

Odds of Being Engaged During Activities - Finland

\begin{tabular}{lccc}
\hline Activity & Odds Ratio & Standard Error & p-value \\
\hline Listening & $0.84^{*}$ & .07 & .04 \\
Discussing & 0.88 & .12 & .35 \\
Writing & 1.07 & .14 & .59 \\
Calculating & $2.16^{* * *}$ & .34 & .00 \\
Testing & 1.13 & .27 & .61 \\
Computer & 0.95 & .26 & .86 \\
Group Work & 1.05 & .13 & .71 \\
Lab Work & 0.69 & .16 & .11 \\
Presenting & $3.38^{* *}$ & 1.31 & .00 \\
Other & 0.72 & .15 & .12 \\
\hline Note. Comparisons are between observations in each category of activity and all other categories of \\
activities combined. \\
$* p<0.05 . * p<0.01 . * * *<0.001$. & & \\
\hline
\end{tabular}

Table 4

Odds of Being Engaged During Activities - U.S.

\begin{tabular}{lccc}
\hline Activity & Odds Ratio & Standard Error & p-value \\
\hline Listening & $.66^{* *}$ & .09 & .00 \\
Discussing & $1.42^{* *}$ & .19 & .01 \\
Writing & .91 & .14 & .54 \\
Calculating & 1.42 & .30 & .10 \\
Testing & 1.67 & .96 & .38 \\
Computer & .84 & .22 & .52 \\
Group Work & 1.20 & .20 & .26 \\
Lab Work & 1.05 & .20 & .81 \\
Presenting & 2.38 & 1.33 & .12 \\
Other & 0.68 & .16 & .10 \\
\hline Note. Comparisons are between observations in each category of activity and all other categories of \\
activities combined. \\
${ }^{*} p<0.05 . * p<0.01 . * * * p<0.001$. & & \\
\hline
\end{tabular}

In The U.S., students reported the highest levels of situational engagement when discussing —approximately 1.42 times higher than when doing other activities_-approximately a three percentage point increase in the proportion of responses where students were situationally engaged. Given that in both countries students were less likely to be situationally engaged when listening, the question then becomes how different is the situational engagement in each 
SCIENCE CLASSROOM ACTIVITIES

of these activities compared to all other ones. With respect to lower levels of situational engagement, the U.S. sample had a 0.66 odds ratio for listening — or roughly three percentage points less than the other activities.

\section{Discussion}

Based on our results, science classroom activities are associated with different levels of student situational engagement. This study makes a contribution in that there are few empirical studies of situational engagement related to science classroom activities (Hampden-Thompson \& Bennett, 2013; King et al., 2015). Our results show that situational engagement occurs relatively infrequently in science classrooms in randomly selected situations. Student situational engagement was measured three times in science lessons across twelve days. in the Finnish sample the students report considerably higher levels of situational engagement than the U.S. students.

According to our sample, Finnish students reported that they spent most of their time listening. This result is in line with a Finnish survey study according to which teachers mostly used lecturing, independent work and laboratory work (Juuti et al., 2010). Another Finnish study revealed that teachers used mostly laboratory work in their lower secondary science lessons (Lavonen \& Laaksonen, 2009). U.S. students spent most of their time listening to lectures and discussing. However, students also spent time in writing and group work. Previous findings from the U.S. revealed that teachers use a variety of classroom activities in their science classrooms (Shernoff et al., 2003; Weiss, 1997).

Results from Tables 1 and 2 were corroborated by the hierarchical analysis in that situational engagement appears less likely when students are inactive and listening to the teacher lecture in both of the countries - a finding consistent with the work of Shernoff and 
SCIENCE CLASSROOM ACTIVITIES

colleagues (2003). Also, in the U.S., students were more likely to be situationally engaged when discussing which support the findings by Good and Brophy (2003). Surprisingly, Finnish student reported higher level of situational engagement when they were presenting material such as the outcome of an investigation or calculating. Although, for example, "presenting material" in Finland has high levels of situational engagement, it makes up a very small portion of class time. It is unclear whether students would be as engaged if presenting took up a larger portion of the classroom activities.

While there are several outcomes of the research which could be applied to practice, the selected activities cover only part of the classroom activities that are used in upper secondary science classrooms. Keeping in mind that the results should be replicated before generalizing, there are some recommendations for teachers and teacher educators. According to our results, a teacher could increase the number of situations where students use calculation to solve problems to get more situationally engaged students in Finland. In the U.S., student situational engagement could be increased by letting students discuss more as a group or in pairs. In both countries, teachers could reduce activities that requires students listening to lectures to avoid a decrease of student situational engagement.

According to our results, there is considerable variation in how teachers engage in different classroom activities and in how they conduct their science lessons which are associated with different measures of situational engagement. For example, the choice between listening and instead having students engage in discussion seems like a reasonable strategy for enhancing situational engagement. Our results also indicate that all of the reported activities we identified are engaging for some students. In other words, there were no activities where the reported situational engagement would have been zero. However, we would not expect that individuals are going to be situationally engaged in science all the time. 


\section{Limitations}

There are several limitations to this study. The student and classroom samples are purposive and not generalizable to the populations of either country. Nor should conclusions be drawn about the differences between countries. However, it is remarkable that there was similarity in the student responses in both countries especially regarding time in situational engagement. Furthermore, students in both countries were less engaged when they were listening. These results are descriptive and not causal. Nonetheless, the results for lecture are consistent with other studies and the recollections of adults who took science classes in secondary school.

Although our sampling with the ESM was representative of how time was spent on the days we collected information, since we gathered information from multiple randomly selected times in one lesson, the data may not be representative of the total time the teachers spent on activities over the course of weeks or a semester. For example, in the U.S., we suspect that testing is responsible for a larger proportion of classroom time than we captured which may affect overall situational engagement and science learning as evidenced by PISA results (OECD, 2014).

The data collection itself caused some limitations. For example, some of the teachers reported that even though there were three randomly selected signals in one lesson, ESM questionnaires did not cover all of the activities used. The ESM itself did stop students' participation in classroom activities while students responded and it may have interrupted their experience of situational engagement. However, it took less than two minutes to answer the ESM questionnaire, so interruptions were short. Moreover, the ESM questionnaire was the same each time, which made the answering process faster after students' first few 
SCIENCE CLASSROOM ACTIVITIES

responses. There were also some minor technical problems with the data collection. For instance, some of the students reported that they received less signals than expected. One common reason for that was the time setting of the smartphone, which if wrong may have prevented the signals from occurring at the pre-scheduled times.

\section{Future studies}

This research focused on the association between classroom activities and student situational engagement. Descriptive statistics related to challenge, skill and interest together with classroom activities were also reported. However, the actual analysis was more focused on situational engagement, not skill, interest and challenge separately. A closer look at skill, interest, and challenge could give more insight into how classroom activities are directly associated with each precondition. For example, Finnish students reported high levels of skill and interest, but low level of challenge when participating in laboratory work based on the descriptive analysis. In the U.S., presenting led into a similar phenomenon. By looking at how different classroom activities are associated with the preconditions of situational engagement, we would be able to see how a specific classroom activity could be improved to support student situational engagement. For instance, in the Finnish example described above, laboratory work could be more situationally engaging for students if it would offer more challenge.

In the Finnish sample, calculating seem to increase the possibility for student situational engagement. In the future, more detailed data should be collected on the content of the lesson so that we know more about the contexts in which students are using calculation. Previous research has also shown that different motivational and contextual factors such as motivational beliefs and teacher and peer support, influence student engagement (Fredricks, 
SCIENCE CLASSROOM ACTIVITIES

Hofkens, Wang, Mortenson, \& Scott, 2017). Classroom observations such as video recordings or detailed notes from classrooms could expand the knowledge of how students engage in science classrooms, beyond just the type of activity they report doing.

Our results point out that presenting in Finland and discussing in the U.S. increased the possibility of student situational engagement. To be able to suggest to teachers and teacher educators what science classroom activities should be used in lessons, replicative research with bigger and more representative sample size is needed. However, we offer evidence that the activities teachers use in secondary science classes matter for eliciting students' situational engagement. Although, blanket statements about which activities teachers should use are beyond the scope of our findings, further work to identify the contextual factors that make some activities more situationally engaging and for whom could provide informative guidance for science teachers.

\section{References}

Abrahams, L. (2009). Does practical work really motivate? A study of the affective value of practical work in secondary school science. International Journal of Science Education, 31(17), 2335 - 2353. https://doi.org/10.1080/09500690802342836

Ainley, M., \& Ainley, J. (2011). Student engagement with science in early adolescence: The contribution of enjoyment to students' continuing interest in learning about science. Contemporary Educational Psychology, 36, 4-12.

https://doi.org/10.1016/j.cedpsych.2010.08.001

Ainley, M., Hidi, S., \& Berndorff, D.(2002). Interest, learning and the psychological processes that mediate their relationship. Journal of Educational Psychology, 94, 545 - 561. http://dx.doi.org/10.1037/0022-0663.94.3.545 
SCIENCE CLASSROOM ACTIVITIES

Brophy, J. (2004). Motivating students to learn (2 ${ }^{\text {nd }}$ ed.). Mahwah, NJ, US: Lawrence Erlbaum Associates Publishers.

Brophy, J. (2008). Motivating students to learn (2nd ed.). Mahwah, NJ: Lawrence Erlbaum Associates.

Corso, M. J., Bundick, M. J., Quaglic, R. J., \& Haywood, D. E. (2013). Where students, teacher, and content meet: Student engagement in the secondary classroom. American Secondary Education, 41(3), 50 - 61.

Csikszentmihalyi, M. (1990). Flow: The psychology of optimal experience. New York: Harper Perennial.

Csikszentmihalyi, M. (2014). Applications of flow in human development and education. New York: Springer Dordrecht Heidelberg.

Csikszentmihalyi, M., \& Schneider, B. (2000). Becoming adult. How teenagers prepare for the world of work. New York, NY: Basic Books.

Duit, R., \& Confrey, J. (1996). Reorganizing the curriculum and teaching to improve learning in science and mathematics. In D.F. Treagust, R. Duit, and B. J. Fraser (Eds.), Improving Teaching and Learning in Science and Mathematics. New York: Teachers College Press. (pp. 79 - 93).

Finn, J. D., \& Zimmer, K. S. (2012). Student engagement: what is it? Why does it matter?. In S. L. Christenson, A. L. Reschly, \& C. Wylie (Eds.), Handbook of research on student engagement (pp.97-131). New York: Springer Sciences.

Fredricks, J. A., Blumenfeld, P. C., \& Paris, A. H. (2004). School engagement: Potential of the concept, state of the evidence. Review of Educational Research, 74(1), 59-109. https://doi.org/10.3102/00346543074001059 
SCIENCE CLASSROOM ACTIVITIES

Fredricks, J. A., Hofkens, T., Wang, M.-T., Mortenson, E., \& Scott, P. (2017). Supporting girls' and boys' engagement in math and science learning: A mixed methods study. Journal of Research in Science Teaching, 55(2), 271 - 298. https://doi.org/10.1002/tea.21419

Good, T. L., \& Brophy, J. E. (2003). Looking in classrooms. Boston: Pearson/Allyn and Bacon Publishers.

Hampden-Thompson, G., \& Bennett, J. (2013). Science teaching and learning activities and students' engagement in science. International Journal of Science Education, 35(8), 1325 - 1343. https://doi.org/10.1080/09500693.2011.608093

Hektner, J. M., Schmidt, J. A., \& Csikszentmihalyi, M. (2007). Experience Sampling Method. Measuring the quality of everyday life. Thousand Oaks, CA: Sage Publications.

Hidi, S., \& Renninger, K. A. (2006). The four-phase model of interest development. Educational Psychologist, 41, 111-127. https://doi.org/10.1207/s15326985ep4102_4

Hidi, S., Renninger, A., \& Krapp, A. (2004). Interest, a motivational variable that combines affective and cognitive functioning. In D. Y. Dai \& R. J. Sternberg (Eds.), Motivation, emotion, and cognition (pp. 89 - 115). Mahwah, NJ: Lawrence Erlbaum.

Jeong, J. G. (2005). Obtaining accurate measures of time use from the ESM. In Being Together, Working Apart: Dual-Career Families and the Work-Life Balance,. B. Schneider and L. Waite (Eds.). New York: Cambridge University Press. 
SCIENCE CLASSROOM ACTIVITIES

Juuti, K., Lavonen, J., Uitto, A., Byman, R., \& Meisalo, V. (2010). Science teaching methods preferred by grade 9 students in Finland. International Journal of Science and Mathematics Education, 8(4), 611 - 632. https://doi.org/10.1007/s10763-009-91778

King, D., Ritchie, S., Sandhu, M., \& Henderson, S. (2015). Emotionally intense science activities. International Journal of Science Education, 37(12), 1886 - 1914. https://doi.org/10.1080/09500693.2015.1055850

Krajcik, J., S., \& Shin, N. (2014). Project-based learning. In R.K. Sawyer (Ed.), Cambridge Handbook of the Learning Sciences (2 ${ }^{\text {nd }}$ editionpp. 275 - 297). New York: Cambridge.

Krapp, A. (2000). Interest and human development during adolescence: An educational psychological approach. In J. Heckhausen (Ed.), Motivational psychology of human development (pp. 109 - 128). London: Elsevier.

Lavonen, J. (2007). National science education standards and assessment in Finland. In D. N. Waddington, (Ed.), Making it comparable (pp. 101 - 126). Berlin: Waxmann.

Lavonen, J., Angell, C., Byman, R., Henriksen, E. K., \& Koponen, I. T. (2007). Social interaction in upper secondary physics classrooms in Finland and Norway: A survey of students' expectations. Scandinavian Journal of Educational Research, 51(1), 81 - 101. https://doi.org/10.1080/00313830601079082

Lavonen, J., \& Laaksonen, S. (2009). Context of teaching and learning school science in Finland: Reflections on PISA 2006 results. Journal of Research in Science Teaching, 46(8), 922 - 944. https://doi.org/10.1002/tea.20339 
SCIENCE CLASSROOM ACTIVITIES

Lederman, N. G., \& Lederman, J.S. (2007). Standards for science education in the United States: Necessary Evil? In P. N. Waddington (Ed.), Making it comparable (pp. 347 373). Berlin: Waxmann.

Lee, W., Lee, M. J., \& Bong, M. (2014). Testing interest and self-efficacy as predictors of academic self-regulation and achievement. Contemporary Educational Psychology, 39(2), $86-99$.

Linnansaari, J., Viljaranta, J., Lavonen, J., Schneider, B., \& Salmela-Aro, K. (2015). Finnish students' engagement in science lessons. Nordisk tidsskrift i naturfagdidaktikk, 11(2), $192-206$.

Millar, R. (2011). Practical work. In J., Osborne, \& J. Dillon (Eds.), Good practice in science teaching. What research has to say, $2^{\text {nd }}$ edition (pp. $\left.108-134\right)$. Buckingham: Open University Press.

Mulligan, C. B., Schneider, B., \& Wolfe, R. (2005). Non-response and population representation in studies of adolescent time use. Electronic Journal of Time Use Research, 2(1), $33-53$.

Nakamura, J., \& Csikszentmihalyi, M. (2014). The concept of flow. In M. Csikszentmihalyi (Ed.), Flow and the Foundation of Positive Psychology (pp. 239 - 263). Netherlands: Springer Science + Business Media.

OECD. (2014). PISA 2012: Results in focus. Paris, France: OECD Publishing.

Osborne, J., Simon, S., \& Collins, S. (2003). Attitude towards science: A review of the literature and its implications. International Journal of Science Education, 25(9), 1049 - 1079. https://doi.org/10.1080/0950069032000032199 
SCIENCE CLASSROOM ACTIVITIES

Raudenbush, S. W., \& Bryk, A. (2002). Hierarchical linear models (2nd ed.). Thousand Oaks, CA: Sage Publications.

Salmela-Aro, K., Moeller, J., Schneider, B., Spicer, J., \& Lavonen, J. (2016). Integrating the light and dark sides of student engagement using person-oriented and situationspecific approaches. Learning and Instruction, 43, $61-70$. https://doi.org/10.1016/j.learninstruc.2016.01.001

Salmela-Aro, K., \& Upadyaya, K. (2014). Developmental trajectories of school burnout: Evidence from two longitudinal studies. Learning and Individual Differences, 36, 60 - 68. http://dx.doi.org/10.1016/j.lindif.2014.10.016

Schmidt, J. A., Rosenberg, J. M., \& Beymer, P. N. (2017). A person-in-context approach to student engagement in science: Examining learning activities and choice. Journal of Research in Science Teaching. https://doi.org/10.1002/tea.21409

Schneider, B., Krajcik, J., Lavonen, J., Salmela-Aro, K., Broda, M., Spicer, J., Bruner, J., Moeller, J., Linnansaari, J., Juuti, K., \& Viljaranta, J. (2016). Investigating optimal learning moments in U.S. and Finnish science classes. Journal of Research in Science Teaching, 53(3), 400 - 421. https://doi.org/10.1002/tea.21306

Shernoff, D. J., \& Csikszentmihalyi, M. (2009). Flow in schools. Cultivating engaged learners and optimal learning environments. In R. Gilman, E. S. Heubner, \& M. J. Furlong (Eds.), Handbook of Positive Psychology in Schools (pp. 131 - 145). New York, NY: Routledge.

Shernoff, D., Csikszentmihalyi, M., Schneider, B., \& Shernoff, E. (2003). Student engagement in high school classrooms from the perspective of flow theory. School Psychology Quarterly, 18(2), 158-176.

http://dx.doi.org/10.1521/scpq.18.2.158.21860 
SCIENCE CLASSROOM ACTIVITIES

Upadyaya, K., \& Salmela-Aro, K. (2013). Development of school engagement in association with academic success and well-being in varying social contexts: A review of empirical research. European Psychologist, 18(2), 136 - 147. http://dx.doi.org/10.1027/1016-9040/a000143

Velayutham, S., Aldridge, J., \& Fraser, B. (2011). Development and validation of an instrument to measure students' motivation and self-regulation in science learning. International Journal of Science Education, 33(15), 2159 - 2179. https://doi.org/10.1080/09500693.2010.541529

Weiss, C. H. (1997). Theory-based evaluation: Past, present, and future. New Directions for Evaluation, Special Issue: Progress and Future Directions in Evaluation: Perspectives on Theory, Practice, and Methods, 76, $41-55$. https://doi.org/10.1002/ev.1086

Wu, H.-S., \& Huang, Y.-A. (2007). Ninth-Grade student engagement in teacher-centred and student-centred technology-enhanced learning environments. Science Education, 91(5), 727 - 749. https://doi.org/10.1002/sce.20216 